\title{
Development of a test system for simultaneous detection of HIV RNA and Hepatitis C virus (HCV) and DNA of Hepatitis B virus (HBV) in blood samples
}

\author{
Nader Shahrokhi ${ }^{1 *}$, Masoud Hajia ${ }^{2}$, Maysam Shahrokhi², Foroozan Abbasi², Mohamad Farzaneh-khah² \\ From $16^{\text {th }}$ International Symposium on HIV and Emerging Infectious Diseases \\ Marseille, France. 24-26 March 2010
}

\section{Background}

The aim of this work was to create a PCR test systems for simultaneous detection of HIV RNA, HCV RNA and DNA of HBV, which will have high sensitivity and high bandwidth.

The issue of viral safety of blood products is of particular relevance in relation to the epidemiological situation with regard to viral hepatitis and HIV infection. The use of serological tests for screening of blood products has significantly reduced the risk of transmission of these infections in the transfusion. But from the moment of infection until the appearance of antibodies to the virus may be a considerable period, known as «serological window». In this situation, great care may have tests to detect the virus itself or its components. Using molecular genetics methods of diagnosis helped reduce the period of «serological window» and improve the safety of transfusion.

The actual development of low-cost highly sensitive tests, allowing both to detect HIV and hepatitis viruses $\mathrm{B}$ and $\mathrm{C}$, increase the capacity of blood transfusion stations in the molecular genetic studies. This involves the basic requirements for test systems for screening of donated blood - the highest analytical sensitivity.

\section{Methods}

To increase the sensitivity and specificity of multiplex PCR, a novel Dual Priming Oligonucleotide (DPO) technology was used. This system is structurally and functionally different from the primer system currently in

\footnotetext{
* Correspondence: n_shahrokhi@yahoo.com

${ }^{1}$ Pasteur Institute of Iran, Tehran, Iran, Islamic Republic of
}

wide-spread use blocked extension of non-specially primed templates, and thereby generates consistently high PCR specificity even under less than optimal PCR conditions. The DPO primer system includes a poly(I) linker between two unequal segments of primer sequences. The poly(I) linker forms a bubble-like structure that separates a single primer into two functional regions, thereby increasing specificity. Furthermore, because the bubble like structure of its poly(I) linker efficiently prevents primer-dimer and hairpin structure formation, the DPO system is more accurate for multiplex PCR applications. The test system developed for the simultaneous detection of nucleic acids of HIV, $\mathrm{HCV}$ and HBV, involves extraction of RNA/DNA from individual samples (100-1000 $\mu \mathrm{l})$. The selected RNA/ DNA is added to tubes containing the reaction buffer for RT-PCR combined with reverse transcription. Detection of amplification products was done by using the TaqMan technology.

\section{Results}

To determine the analytical sensitivity and the inhibitory influence of concomitant diseases, a number of experiments on model samples containing all three infectious agent in different concentrations were done. The test system allows both to identify nucleic acids of HIV, $\mathrm{HCV}$ and HBV with a sensitivity of $50 \mathrm{RNA}$ copies/ml (for HIV), $10 \mathrm{IU} / \mathrm{ml}$ (for HCV) and 20 copies of DNA/ $\mathrm{ml}$ (for HBV).

\section{Discussion}

To use a molecular diagnostic method in the service of blood in order to increase the viral safety should be 
developed test-system with high sensitivity and high bandwidth. In this regard, we develop a DPO-multiplex PCR, for simultaneous detection of HIV nucleic acids and viruses of hepatitis B and C. The proposed format is a low cost and high throughput. We also showed that the DPO-PCR method was successfully utilized for multiplex amplification with a little amount of test samples with high sensitivity and specificity because of high accuracy of priming during PCR.

\section{Author details}

${ }^{1}$ Pasteur Institute of Iran, Tehran, Iran, Islamic Republic of. ${ }^{2}$ Noor Medical Laboratory, Tehran, Iran, Islamic Republic of.

Published: 11 May 2010

Cite this article as: Shahrokhi et al:: Development of a test system for simultaneous detection of HIV RNA and Hepatitis C virus (HCV) and DNA of Hepatitis B virus (HBV) in blood samples. Retrovirology 2010

7(Suppl 1):P169.

Submit your next manuscript to BioMed Central and take full advantage of:

- Convenient online submission

- Thorough peer review

- No space constraints or color figure charges

- Immediate publication on acceptance

- Inclusion in PubMed, CAS, Scopus and Google Scholar

- Research which is freely available for redistribution

Submit your manuscript at www.biomedcentral.com/submit 